Portland State University

PDXScholar

\title{
Emerging Discourse Incubator: The Roles of Institutional Complexity and Hybridity in Social Impact Supply Chain Management
}

\author{
Madeleine E. Pullman \\ Portland State University, mpullman@pdx.edu \\ Annachiara Longoni \\ Ramon Llull University \\ Davide Luzzini \\ EADA Business School
}

Follow this and additional works at: https://pdxscholar.library.pdx.edu/busadmin_fac

Part of the Operations and Supply Chain Management Commons Let us know how access to this document benefits you.

\section{Citation Details}

Pullman, Madeleine E.; Longoni, Annachiara; and Luzzini, Davide, "Emerging Discourse Incubator: The Roles of Institutional Complexity and Hybridity in Social Impact Supply Chain Management" (2018). Business Faculty Publications and Presentations. 99. https://pdxscholar.library.pdx.edu/busadmin_fac/99

This Post-Print is brought to you for free and open access. It has been accepted for inclusion in Business Faculty Publications and Presentations by an authorized administrator of PDXScholar. Please contact us if we can make this document more accessible: pdxscholar@pdx.edu. 


\title{
Journal of \\ Supply Chain Management
}

\section{THE ROLES OF INSTITUTIONAL COMPLEXITY AND HYBRIDITY IN SOCIAL IMPACT SUPPLY CHAIN MANAGEMENT}

\author{
Madeleine Pullman, Annachiara Longoni, Davide Luzzini
}

Article information: Madeleine Pullman, Annachiara Longoni \& Davide Luzzini (2018) "The roles of institutional complexity and hybridity in social impact supply chain management," Journal of Supply Chain Management, Vol 54, Issue 2.

\begin{abstract}
Supply chain research and practice has moved beyond green or environmental issues to include social issues. But much of the focus still remains on attempts of large companies to reduce social harm along their supply chains rather than creating social good. At the same time, research investigating the role of NGOs in supply chains or humanitarian logistics often emphasizes temporary initiatives and overlooks long term viability. This conceptual paper seeks to expand the playing field by looking at how social enterprises manage their supply chains to generate social benefit while maintaining or improving their financial viability in the long term. Our contribution is to consider those socially motivated organizations that lie on the continuum between purely social and purely commercial enterprises. We consider how these organizations manage their supply chains for social impact and define this area as social impact supply chain management (SISCM). In this work, we view these organizations and managerial issues through the lens of institutional complexity, i.e. the presence of multiple and possibly conflicting institutional logics in the focal organization. We propose that for these organizations, supply chain strategy, stakeholder identification and engagement, and relationship management might differentiate SISCM from traditional supply chain management. And as a result, we offer future research directions that might add clarity to effective SISCM.
\end{abstract}

Keywords: Social Responsibility, Social Enterprise, Sustainability, Institutional Complexity 


\section{THE ROLES OF INSTITUTIONAL COMPLEXITY AND HYBRIDITY IN SOCIAL IMPACT SUPPLY CHAIN MANAGEMENT}

\section{INTRODUCTION}

Can businesses really solve social problems? Many are questioning if any firm can manage its supply chain to do this job in a long term sustainable way (Pagell \& Shevchenko, 2014). A firm may come up with a treatment for a major disease, a noble social goal, but that firm and its supply chain partners mark that treatment up to exorbitant price levels to meet their shareholder priorities. From cancer and AIDS treatments to remedies for snake bites or bee sting allergies, firms often extract high profits at the expense of the needy patients (Kantarjian, 2015; Lewis, 2015; Woodyard \& Layton, 2016). Likewise, many businesses feel that job creation contributes to their community and society but then lay off employees or shutter plants as soon as profitability goals are not met (Moon \& Sochacki, 1996). On the other hand, non-profit organizations must depend on external sources of funding such as public money or charity and thus lack financial stability. Increasingly, for-profit businesses are being pressured to take social objectives more seriously not only from consumers but from investors, employees, and social media. Thus, their level of participation in social programs correlates with investor interest, market value and the bottom line (The Economist, December 2017).

Either way, the trade-offs created by social goals and profit motivation rarely create long term sustainable solutions. One of the main reasons is that firms struggle to both reconcile incompatible prescriptions that arise from multiple logics characterizing their institutional environment, namely a commercial and a social-welfare logic, and implement these prescriptions into viable supply chain management (SCM) approaches. As a result, social enterprises have emerged as a possible answer. These enterprises pursue a social goal enabled by an economic activity and manage their supply chain accordingly. For example, Semi Di Libertà, an Italian social enterprise integrates incarcerated prisoners into the production of a high quality artisan beer so that they can be trained and placed in brewery jobs when their prison term finishes (Mapelli, Arena \& Strano, 2016).

What makes social enterprises interesting is their hybrid nature. Specifically, they try to provide organizational answers to the social-welfare and the commercial logics characterizing the institutional environment in which they are embedded (Pache and Santos, 2013). While for- 
profit businesses rely on market activities and non-profits and NGOs that are specifically social mission-oriented rely on contributions from donors, social enterprises are mission-oriented ventures that both compete in the market and address complex social problems (Battilana \& Lee 2014; Dacin, Dacin, \& Tracey, 2011). In the Semi Di Libertà example, the beer production represents a response to the social-welfare logic and, conversely, the social-welfare logic is part of the brand and enables the commercial logic. This hybrid nature gives rise to unusual organizational strategies and structures that have increasingly attracted research attention (e.g. Battilana \& Lee, 2014).

Social enterprises require a hybrid organizational model affecting many elements such as: organizational forms and structures, governance, workforce composition, organizational activities, collaboration and formalization, incentives, control, and professional legitimacy (Pache \& Santos, 2013; Battilana \& Lee, 2014; Ramus, Vaccaro \& Brusoni, 2017). This particular organizational model allows organizations to prioritize social impact instead of solely focusing on profits thus serving dual purposes. A social enterprise steps in when public and private organizations fail to provide long term solutions to a social problem. In so doing, social enterprises often break conventions, span sectoral boundaries, and experiment with different ways of organizing and managing. The ultimate objective is triggering catalytic or systemic change (Mair, Battilana, \& Cardenas, 2012).

At the supply chain level, making sense of and responding to both social-welfare and commercial logics is also challenging. However, while we are seeing the emergence of research considering non-governmental organizations (NGO) partnerships in supply chains (Pagell \& Wu, 2009; Rodríguez, Giménez, Arenas, \& Pagell, 2016), very little research has examined how other types of entities including social enterprises act as focal actors in supply chains to achieve a social goal while being economically viable. In this study, we examine the case of social enterprises that pursue their mission as focal actors and discuss how they can manage their supply chains. We will refer to this focus area as social impact supply chain management (SISCM), meaning how a social enterprise manages its supply chain to fulfil its social mission and achieve economic viability.

Since current literature does not offer many insights on how social enterprises manage their supply chains, in this paper, we consider how the hybrid business models of these focal organizations translate into specific SISCM strategies and practices. Any organization with a 
social mission is typically part of a supply chain with multiple stakeholders necessitating interacting with these players to solve the social problem. However, social enterprises are unique organizations so their approach to management of their supply chain may differ from the forprofit entities that supply chain scholars typically study. Therefore, by studying SISCM, we hope to contribute to the research considering better solutions to complex social problems. This focus is in line with Lee \& Tang's (2017) survey of supply chain and operations literature where they found that the social innovation and social responsibility receive significantly less attention than sustainability (typically implying environmental issues) overall. And as SISCM is at the crossroad between social entrepreneurship and SCM literature, we see a research gap that needs to be addressed.

\section{SOCIAL IMPACT SUPPLY CHAIN MANAGEMENT}

Supply chain management can be defined as the "management of a network of relationships within a w and between interdependent organizations and business units" and also "the forward and reverse flow of materials, services, finances and information” (Stock \& Boyer 2009, p. 691). For supply chain researchers, a focal firm or organization creates and manages the supply chain but may or may not be the firm that provides the final good or service to the end customer. The focal organizations involved with SISCM, social enterprises, fall under the social entrepreneurship literature, a common "umbrella” under which studies about the formation of organizations addressing a social issue are collected (Battilana \& Lee, 2014). Most social enterprise literature neglects supply chain management with the exception of Battilana \& Lee (2014) or Sodhi and Tang (2011; 2016) where the authors consider inter-organizational relationships as an important component of social enterprises. In the supply chain literature, few studies investigate social enterprises and it lacks a framework to study the phenomenon.

SISCM strategies and practices are context-specific and depend upon the social mission and the industry where the focal company operates. However, one common aspect to all social enterprises is the need to blend into their supply chain management both commercial and socialwelfare logics. We are interested in understanding how this happens and how some key SCM practices may need to be reconsidered for SISCM.

In order to support this endeavor, we introduce an institutional logics perspective of SISCM as a potential theoretical foundation to describe how the focal organizations answers to multiple 
competing logics. Additionally, we describe different approaches to SISCM that social enterprises adopt when combining commercial and social-welfare logics. Previous literature on social enterprises and institutional logics proposes a continuum between two types: the purely commercial and the purely social (Dees \& Elias, 1998). These organizations follow different institutional logics, meaning principles that prescribe "how to interpret organizational reality, what constitutes appropriate behavior, and how to succeed” (Thornton, 2004, p. 70).

Social enterprise literature has recognized the presence of multiple logics within an organization (Dacin, Dacin, \& Tracey, 2011). Institutional complexity is the term used in the literature to indicate the presence of multiple and potentially conflicting institutional logics (Greenwood et al., 2011, p. 317). A particular logic may be core to organizational functioning such that it determines the core work tasks; another logic may be accommodated through activities and structures more peripheral to organizational functioning (Meyer \& Rowan, 1977). In some cases, multiple institutional logics occur at the core, permeating all work tasks, rather than being split into core and periphery (Pache \& Santos, 2013). Besharov and Smith (2014) refer to centrality as the degree to which multiple logics are treated as equally valid and relevant. Since social enterprises answer to multiple logics, we expect that - as focal organizations - they will manage their supply chains differently than for-profit enterprises, where the commercial logic prevails. Previous SCM research lacks specificity about how focal organizations might manage supply chains with both social-welfare and commercial logics.

In this study, we address an apparent void in the literature, i.e. the possible SISCM approaches to cope with institutional complexity. In particular, we identify how specific SCM practices are changed (i.e. strategy, stakeholder identification and engagement, and relationship management) by social enterprises in SISCM along the continuum between the purely commercial and purely social extremes.

\section{SISCM CONTINUUM}

We argue that social enterprises adopt different SISCM approaches as a response to multiple institutional logics along a continuum between the purely commercial and purely social types. These SISCM approaches are different from traditional SCM due to its limited capability to address this kind of institutional complexity. SISCM approaches are adopted by social 
enterprises to fulfil the social mission while making economic sense. We take the perspective of the social enterprise as the focal organization managing its supply chain and the object of analysis is its SISCM approach.

At the extremes of this continuum there will be focal organizations that manage their supply chains through a purely commercial or social-welfare, respectively. The former is structured around the goal to sell products and services on the market to produce an economic surplus that can ultimately be appropriated by owners (Friedland \& Alford, 1991); whereas the latter mainly makes products and services available to address social needs (Pache \& Santos, 2013). At either end, organizations consciously or unconsciously reject institutional complexity when dealing with SCM decisions in favor of a more simplistic view that privileges a commercial or socialwelfare logic. Despite the simplification, some limitations might arise due to this choice. On the one hand, purely commercial SCM might result in a limited scope of social impact; on the other hand, purely social SCM might result in financial instability depending on the availability of funding. Alternatively, social enterprises that are in the continuum between the purely commercial and purely social extremes manage their supply chains in innovative ways to deliver social good and while protecting their economic viability. We argue this balance is representative of social enterprises who need to find new ways to combine the social-welfare and commercial logics.

Purely commercial SCM is typically studied in traditional SCM research while purely social SCM has been the purview of humanitarian logistics scholars. We note that the supply chains of each of these focal organizations might incorporate suppliers representing the alternative logic for various reasons. For example, a for-profit organization may hire some disadvantaged employees or the humanitarian relief organization may hire a for-profit logistics company. However, there is minimal assimilation of the alternative logic in a meaningful way by the focal organization and in their SCM activities. Between these two extremes, social enterprises experience different levels of assimilation of the social and commercial logics in a systematic fashion in performing SISCM.

Even though the purely commercial and purely social SCM are characteristic of the focal organizations at the extremes of the continuum, they are not discussed here for two reasons. First, they do not address institutional complexity as one logic usually dominates. Therefore, they do not fit the SISCM definition. Second, both purely commercial or social SCM have been 
studied already by their respective research streams. Therefore, while these two SCM approaches provide the end points for our continuum, they are not considered part of the SISCM scope in this paper.

We move beyond traditional SCM dominated by one logic to describe three hybrid approaches to SISCM: Decoupled, Combinatory, and Coupled. These three approaches are neither exhaustive of the potential types nor can we claim that they are mutually exclusive or complete; instead they are a starting point in the discussion of SISCM and how it might be different than traditional SCM. We highlight their specificities in terms of strategies, stakeholder identification and engagement, and relationship management in the supply chain as a response to the institutional complexity generated by the combination of the social and commercial logics. Table 1 and Figure 1 summarize the main characteristics of these approaches.

[Insert Figure 1 Here]

[Insert Table 1 Here]

\section{Decoupled SISCM}

We define Decoupled SISCM as a situation characterized by a focal organization in which the one logic is core and the other logic is peripheral. We discuss the situation where the commercial logic is core because this is presently much more common in practice, but we address the situation of the social-welfare logic being core when discussing future research opportunities. Pache and Santos (2013) propose that when an organization is primarily embedded in one logic but operating in a complex institutional environment characterized by both commercial and social-welfare logics, it can decouple its formal structure from its operational structure to reduce logic conflicts. In other words, this means that the organization symbolically endorses practices prescribed by one logic while actually implementing practices promoted by another logic, often one that is more aligned with its organizational goals.

The focal organization adopting the Decoupled SISCM approach might be a firm that identifies business opportunities in an emerging market and designs a product or service to address needs of people living in these areas by establishing a new business or brand. In many of these cases, these enterprises describe themselves as promoters of better living conditions for these people (social-welfare logic), who are indeed seen as potential final customers and 
consumers (commercial logic). We expect the same decoupling approach to happen in the management of their supply chain. In particular, the focal organization will set up a sociocommercial supply chain, where the commercial logic prevails while formally addressing the social-welfare logic by delivering products or services to people in-need.

Supply chain strategy. As the commercial logic is at the core of the focal organization in Decoupled SISCM, the supply chain strategy will essentially be profit oriented, meaning a way to create value through delivering a product or a service to people in-need. Sodhi and Tang (2016) find that emerging markets present a market opportunity for growth for large fastmoving-consumer-goods and durable goods companies. These enterprises benefit directly from designing a product or a service for these people and selling it to them. Prahalad and Hart (2002) popularized this idea as the Bottom of the Pyramid concept, a proposition that multinational corporations could simultaneously generate profits and make a social contribution through marketing to the poor, the lowest tier of the world's economic pyramid. For example, Unilever produced a small, inexpensive bar of soap which was large enough for washing the face and hands once each day for 10 weeks as part of their Lifebuoy soap brand. Since 2002, the soap has been sold in India and promoted as a way to improve hygiene and prevent diarrhoea. In the first four years, the promotion campaign reached 80 million people; a more recent goal is to reach 1 billion people. This social goal internally translated into a requirement of doubling of sales in five years. This ultimate goal, in line with the commercial logic, resulted in a series of activities that aimed to increase sales and establish distribution networks in both rural and non-rural areas, where people were richer, to more effectively achieve financial goals (Bartlett, 2017).

However, different from traditional SCM, Decoupled SISCM requires the focal organization to not only establish direct relationships in its supply chain with for-profit organizations but also incorporate social entities that understand the target communities. These social entities have earned the trust and loyalty of local communities that they have assisted during challenging times such as war, natural disaster, or poverty relief. Managing the social side of the supply chain is different not only because poor infrastructure and availability of worker skills can limit the size and scope of business units but because the social entities cannot be seen as exploiting the communities for profit. The operational context is similar to the case of humanitarian logistics, but the objective is not to solve a temporary crisis due to exceptional events but to establish long 
term profitable operations with social benefit implications. Therefore, the basic conditions for applicability of classic SCM or humanitarian logistics strategies might not apply and a specific strategy may be required.

Stakeholder identification and engagement. Because commercial logic is at the core of Decoupled SISCM, the focal organization prioritizes both shareholders and beneficiaries intended as customers. But, this focal organization will need to identify and engage directly in its supply chain with stakeholders different from traditional for-profit actors to achieve their ultimate commercial intention. They might need to design a product or service specifically for the identified population in collaboration with local authorities or social entities as well as build and coordinate a local supply chain to distribute products or services that might include both profit and non-profit actors, governments and regulators to deliver the product or service. The focal company will see NGOs, governments or social entities as intermediaries to expand their brand into developing markets.

For example, most Unilever Lifebuoy soap customers live in remote rural areas that are difficult to reach through conventional channels. Unilever worked with NGOs, local entities, and governments to create a direct communication campaign specifically designed to raise awareness among India’s largely rural and often illiterate population. Companies like Nestlé, SC Johnson, and PepsiCo have redesigned food products, cleaners and insecticides to serve the poor. All required rethinking the distribution and financing side of the equation to include local health organizations for delivery of nutrition education and microfinance organizations for payments and loan infrastructure (Brugmann \& Prahalad, 2009; Simanis \& Duke, 2014).

Relationship management. In Decoupled SISCM, the commercial logic is dominant in the focal organization with managers trying to replicate the formal and transactional style of its traditional SCM and understand relationships in terms of power-dependence determined by resource ownership. At the same time, when local social actors act as intermediaries between local communities and the focal organization, the latter might face the challenge of forgoing an arm's length relationship management style in favor of more relationalism.

As a consequence, in Decoupled SISCM, the focal organization most likely maintains traditional power-dominated relationships with some stakeholders, such as market players, 
donors, and governments. However, to gain legitimacy, focal organizations often need the endorsement and support of social actors for their trust. Social actors like NGOs and local community organizations in developed countries are able to influence their localities because they are trustworthy and usually do not exercise power in coercive or formal ways. The focal organization typically needs their help in managing their relationship with local communities. The enforcement of international certification systems for food commodities, such as Utz or Rainforest Alliance, passes through the engagement of local actors that are not merely standardtakers but become directly involved in the implementation, yet not only via classic hierarchical value chains but via an emergent public space (Vellema \& Wjik, 2015).

\section{Combinatory SISC}

The second approach we describe is Combinatory SISCM. In this case, the focal actor is characterized by high centrality with both commercial and social-welfare logics at its core. According to the institutional logics literature, organizations reconcile competing logics by enacting a combination of activities drawn from each logic in an attempt to secure endorsement from a wide range of field-level actors (Pache \& Santos, 2013). The focal organization in this case could be a NGO or non-profit organization (NPO) moving to be more financially selfsupporting through the management of its social activities, a for-profit moving to Benefit (B) corporation status (B Lab, 2018), or a purposefully formed social enterprise, all combining the social-welfare and commercial logics. This combination will be reflected in the supply chain management of the focal organization.

Supply chain strategy. In Combinatory SCM, the focal organization combines, in the same supply chain, actors that mainly adopt a social-welfare logic with actors that mainly adopt a commercial logic, often separated into the downstream or upstream side of their supply chain. For example, when actors adopting the social-welfare logic are on the downstream side, they might employ people-in-need to assemble, distribute, or sell social impact products or services. A popular example of this approach is employed by social enterprises managing the supply chain for solar-products to improve the quality of life for the poor in places like Africa (McKibben, 2017), Haiti (Knuckles, 2016; Bals \& Tate, 2017) and India (Sawal et al., 2015). In these countries, the social enterprises work to set up assembly and/or distribution centres and hire 
locals to market, distribute and install solar products and parts. Another downstream logic example, Vision Spring sells affordable reading glasses to low-income individuals through a network of micro-entrepreneurs in various developing countries; here both the entrepreneurs and eye glass purchasers benefit (Bhattacharya et al., 2010).

Alternatively, when the social-welfare logic actors dominate the upstream side of the supply chain, the focal organization works to include people in need on the supplier side. For example, the social enterprise, Arzu, has the mission of improving the lives of Afghani women so they created an online retail portal to sell traditional and custom designed rugs produced by the women; the social enterprise provides design services to the women and fair prices as well as other social support (Sodhi \& Tang, 2016). The social enterprise, CIFEA provides beekeeping training to members of a Tunisian region with high unemployment but favourable agricultural conditions and a unique ecosystem. After members are in full production, CIFEA then collects, distributes, and commercializes the specially branded organic certified honey and hive products (YUNUS, 2018). Depending on which side of the chain the Combinatory SISCM engages in social impact activities, the commercial side of the chain either finances and distributes needed products or services on the supply side for downstream social impact or sells the products or services to generate economic resources to support the social enterprise activities for the upstream social impact.

The context of the Combinatory SISCM strategy is extremely challenging and unusual compared to traditional SCM strategies. While the focal organization benefits from a broader scope and scale for the distribution of their products (downstream Combinatory) or from unique products and branding opportunities from marginalized group suppliers (upstream Combinatory), they must understand and work with unique SCM challenges such as inadequate infrastructure, novel distribution channels, inadequate training, and different cultural norms around work and financial transactions. Here, the focal organization must actively engage in identifying potential supply chain partners among people in-need, help them to improve or change their products or services to appeal to their customer base, extensively train them in production or distribution skills, manage supply flows in challenging localities, providing information to these partners to operate in the market (Liao \& Chen, 2017; Sodhi \& Tang, 2011).

Additionally, the focal organization goes beyond just employing the workers. The social impact locations are particularly vulnerable not only to life threatening interferences but 
disruptions in material, labour, or product availability, incoming and outgoing deliveries, and exporting and importing regulations that are subject to shifting political agendas. Many focal organizations also participate in the targeted social group's communities and interact with community decision makers to understand how they can help improve social conditions.

Stakeholder identification and engagement. The focal organization combines the socialwelfare and commercial logics in identifying and engaging with relevant stakeholders. Specifically, they will serve beneficiaries, financers, and customers as distinct groups. In Combinatory SISCM, different stakeholders are targeted as a result of different logics. The social-welfare logic prescribes to identify and engage the people in-need at one side of the supply chain and to collaborate with local social actors to help include people in-need in their supply chains. The commercial logic requires identification and engagement with market players that enable the economic activity. Each type of stakeholder will serve a specific role, either on the social or the commercial side. In this sense, stakeholder identification and engagement is about orchestrating the commercial and social stakeholders to comply with the social mission rather than addressing shareholder needs to achieve optimal financial performance. This will imply the inclusion of new actors and roles in the focal organization's supply chain compared to traditional supply chains.

In both downstream and upstream Combinatory SISCM, the social enterprise will need to identify people in-need to become suppliers and/or distributor or retailers (Sodhi \& Tang, 2016). Additionally, it will be crucial to identify partners to support the economic and financial growth of these people (Karnani, 2007). For the solar supply chains mentioned above, the focal social enterprises have identified social impact inventors who then contributed funding to microfinancers and the focal organization to support the development of the supply chain (McKibben, 2017). Generally, the focal organization mobilizes resources and capabilities from better endowed stakeholders to offset other stakeholder's constrained resources (Knuckles, 2016). To accomplish this, the focal organization needs to identify and engage with local entrepreneurs, NPOs, NGOs, and venture capital impact investors for traditional or micro financing consumer loans and supply chain activities. 
Relationship management. With social-welfare and commercial logics having high centrality at the core of the focal organization, Combinatory SISCM aims to protect less powerful actors at one tier of the supply chain and therefore tends to establish collaborative, long-term and altruistic relationships locally, while managing formal and transactional relationships with market actors representing for-profit customers/suppliers. The social enterprise connects people in need with market actors integrating the different relationship management styles prescribed by social-welfare and commercial logics.

Instead of having a market player who needs to gain the trust of local and social actors (like in the Decoupled SISCM), we have a social enterprise operating at one tier of the supply chain who is dependent on market entities' economic resources to achieve its social goal. Therefore, the social enterprise experienced in trust-based relationship with people in need, must also operate in a typically power-dominated, market context. Depending on the varying levels of power asymmetries, trust can be more or less difficult to build. As in the Decoupled, Combinatory SISCM which include a powerful supplier or distributor will need to use formalized contracts to compensate for power asymmetries or the powerful buyer can invest in site-specific assets for less powerful partners.

\section{Coupled SISCM}

The last approach we describe is Coupled SISCM where the focal organizations operate at the nexus of two different supply chains to address respectively social and commercial activities. We focus on socially-focused Coupled SISCM where the focal organization is a social enterprise in which the social-welfare logic is core and the commercial logic is peripheral. We address the situation of the commercial logic being core when discussing future research opportunities. Unlike the Decoupled SISCM, the coupled market and social chains are bridged by a social enterprise as the coupling agent (Gulati \& Puranam, 2009). This coupled fit is also reflected in the management of its supply chain. With a social core, the social enterprise has a main mission to address a social need and an economic activity running in parallel to support this social mission and augment its effectiveness. Each of these parallel supply chains, has suppliers and customers with the focal organization as the connection. 
Supply chain strategy. In Coupled SISCM, focal organizations operate separate but consistent supply chain strategies to feed the social one. In the social supply chain, people inneed are the beneficiaries of a transformative social service where the output is a skilled person; the commercial supply chain performs a separate economic activity providing economic resources for the social supply chain so it can continue operating without depending on donations and external funding. The focal organization is the bridge between these two chains.

An example of Coupled SISCM is provided by the case of the Work Integration Social Enterprises (WISEs) and their supply chains. These social enterprises aim to help unemployed people integrate into the workforce and labour markets (Pache \& Santos, 2013). They deliver their social mission by hiring unemployed people, those with physical or psychological disabilities and populations excluded by the society such as inmates or migrants, for a limited period of time with the objective of helping them acquire the social and technical skills they need to find a job. Thus, they have a social supply chain in place that allows them to identify people in need to hire and place them in the job market. As they work for the WISE, these people produce products and/or services that are then sold to generate revenue, while also developing the technical skills that they need to obtain stable, long-term employment. Thus, the focal organization has a commercial supply chain in place to produce the goods and sell them to the market. The WISE will be the focal actor actively connecting the two supply chains and managing contradictions and synergies between the two.

Another example is the UK organization, Redemption Roasters, which aims to train young prisoners in Aylesbury prison as baristas and coffee roasters. By locating their roasting facility and one of their cafes within the prison itself, Redemption teaches prisoner-students all about coffee origins and taste profiles, roasting, and drink-making as a mechanism to help prisoners get jobs after completing their prison terms and reduce recidivism. The costs of shipping raw materials in and out of prison can be as much as three times higher that of a normal commercial site but Redemption covers the training and additional costs from their profits (Lander, 2017). Here the social supply chain consists of prisoners with their future employers as employercustomers of trained coffee experts while the commercial supply chain includes the raw materials upstream, roasting process, and the coffee purchasers as customers. 
Stakeholder identification and engagement. Like the previous cases, stakeholders can be identified according to their dominant institutional logic. In other words, for-profit actors can be engaged in the commercial supply chain while social actors are engaged in the social supply chain. However, in Coupled SISCM, it might become difficult to clearly distinguish these stakeholder types and the stakeholders themselves will display a hybridization of logics.

In the examples of WISE or Redemption Roasters, on the social supply chain side, the focal firm will engage with social actors as supplier of potential employees as well as social counselling and training services. Additionally, after their value-added training, the focal actor helps the employee find long-term employment. The focal organization interacts with social entities and other partners involved in the inclusion of these people in the society and in the job market. A WISE restaurant that trains disadvantaged workers will engage with other restaurants and hotels as customers. The firms hiring trainees can be considered as pure market actors that hire personnel from the social enterprise just like from any other channel. However, it is not uncommon that these clients are sensitive to the social mission and treat trainees from the social enterprise differently, helping them well beyond what is expected in a traditional business context. Similarly, in the commercial supply chain of the WISE, suppliers are often selected because of shared social goals with the focal organization and customers are usually sensitive to its social mission. Social enterprises adopting Coupled SISCM look for stakeholders to be part of their supply chain that display both social-welfare and commercial logics and do not just orchestrate them as providers of specific resources but actively involve them as partners of both the social and commercial supply chain, sometimes even delegating crucial tasks for the mission achievement.

Relationship management. The focal organization adopting Coupled SISCM is part of two separate supply chains that adopt different logics, have different scopes and strategies, and thus require different relationship management styles. The focal organization could simply adopt more relationalism in the social supply chain and more traditional arm's length style in the commercial supply chain. However, the focal organization might be capable of finding synergies between the two approaches. That happens when, on the one hand, market-oriented relationships with economic actors are reoccurring, building trust as well as enhancing informal and altruistic 
relationships. On the other hand, the relational intensity with the social actors becomes more efficient thanks to methods and tools that reduce the transaction costs.

The social enterprise orchestrates two interconnected supply chains creating complex power dynamics. In the supply chain dominated by the social-welfare logic, the shared dedication to a common cause would support trust and informal relationships while potentially generating risks of opportunistic behaviours, contrasting objectives, and inefficiencies. For example, a Spanish social enterprise, Mescladis, trains migrant employees in their restaurant for future placement in other hotels and restaurants. Language barriers and employee country-of-origin custom differences create challenging customer experiences such as order miscommunications and slow service (Longoni, Luzzini \& Pullman, 2017). In the commercial supply chain, the relationships between the focal firm and its market customers/suppliers would be subject to power asymmetries. However, market players might be sensitive to the role and mission of the social enterprise and want to be associated with it to enhance their image; they can gradually complement or even substitute traditional power-dependent relationships with trust. This can be seen in the Mescladis restaurant where the hiring hotels and restaurants trust the social enterprise in the hiring relationship and even take migrant trainees with questionable legal status and severe personal problems (Longoni et. al., 2017). Typically, it is up to the social enterprise to act as a catalyst and create the basis for a trusting and cooperative climate between the two supply chains characterized by shared values, synergies and resource exchange, and minimum conflicts.

\section{FUTURE RESEARCH IN SOCIAL IMPACT SUPPLY CHAIN MANAGEMENT}

We argue that the combination of social-welfare and commercial logics in focal organizations will lead to differences between SISCM and traditional SCM. We expect the institutional complexity derived by the combination of social-welfare and the commercial logics to inform

different supply chain strategies, stakeholder identification and engagement, and relationship management styles. In the next section, we further elaborate on how extant research in these areas falls short if applied in the context of SISCM and propose corresponding future research directions.

\section{Supply chain strategy}


The first specificity of SISCM is the need to combine the commercial and social-welfare logics in the supply chain strategy. Indeed, focal organizations are embedded in a commercial and a social-welfare logic and need to develop unusual supply chains strategies to address such institutional complexity. The traditional SCM literature usually identifies supply chain strategies as a function of product characteristics such as demand and supply uncertainty leading to the classic supply chain strategies of efficiency, responsiveness, risk hedging, agility, etc. (Fisher et al., 1997; Lee, 2002). These strategies all imply a commercial logic in that the ultimate objective of focal organizations is to maximize profits by finding the appropriate combination between the cost of managing the supply chain and the service level to customers. In this literature, the idea of combing multiple objectives is not new and requires the development of hybrid supply chain strategies, as the literature on mass customization, agility, and lean testifies. However, these studies only consider hybridization of multiple commercial objectives, such as cost and quality (lean strategy) or responsiveness and risk-hedging (agile strategy). Instead, in the SISCM context hybridity can be defined as the combination of social-welfare and commercial logics in an economically viable way (Battilana \& Lee, 2014). This will require future research to understand how to effectively design supply chain strategies that prioritize social objectives, or at least combine social and commercial objectives. Future research might deal with this research direction in descriptive and in normative ways.

Descriptive research opportunities: Identifying SISCM hybrid strategies. Previous research suggests hybridity in traditional SCM, multiple commercial objectives are combined synergistically. For instance, an organization applying lean operations performs the same set of activities to both reduce cost and increase quality (Womack \& Jones, 2010). In the context of SISCM it is not clear what supply chain strategies are available to cope with institutional complexity. Moving beyond the classic cost vs. service trade off, new strategies are needed to achieve a social impact while making economic sense. Additionally, moving toward social goals might imply riskier and sub-optimal strategies in terms of economic goals compared to traditional SCM strategies.

Going beyond the three SISCM types we propose, future research could address other configurations of SISCM such as Decoupled with a social core and commercial peripheral and Coupled SISCM with a commercial core and social peripheral. For example, organizations that 
previously followed the social-welfare logic and were formerly grant funded have move to Decoupled with a social core. UK-based non-profits Emmaus and Sue Ryder, have become sophisticated retailers and supply chain managers, generating a significant portion of their income to support hospice activities and other projects for the needy by generating additional income selling baked goods or used household good (Economist, September 2017).

Similarly, Coupled SISCM with a commercial core and social peripheral are seen with corporations such as Ben \& Jerry’s Partnershops ${ }^{\circledR}$. Similar to WISE programs, Partnershops ${ }^{\circledR}$ are community-based non-profits which offer job and entrepreneurial training to homeless youth in Ben \& Jerry's ice cream stores with a parallel social supply chain with social agencies and potential employers. Here, the corporation provides support and waives franchise fees to Partnershops ${ }^{\circledR}$ (Ben \& Jerry’s, 2018). Future research might look at where these types of SISCM fall on the continuum of social impact as well as taxonomies of different SISCM strategies to understand how such strategies can be implemented across the supply chain and the implications for social impact and financial viability outcomes.

Normative research opportunities: Innovative SISCM strategies. The combination of social-welfare and commercial logics by a focal organization in SISCM might require different solutions than doing it through multiple goal combination or co-joined as prescribed by the institutional logics literature (Pache \& Santos, 2013) and traditional SCM literature (Womack \& Jones, 2010; Christopher \& Towill, 2000). Based on the literature on institutional logics, the combination of multiple logics in SISCM might create different challenges such as risk of mission drift, when one logic (i.e., commercial logic) prevails on the other leading to deprioritizing or abandonment of social concerns in favor of profit-seeking activities (Battilana et al. 2014; Mair et al. 2012). Decoupling instead might lead to identity problems when different activities are managed following different logics (Battilana et al. 2014).

We propose innovative SISCM strategies beyond logic combination and decoupling strategies are needed for social enterprises to effectively manage their supply chains. The innovation occurring in SISCM is expected to include all parties, such as multiple tiers of suppliers, focal organizations, intermediaries, retailers, and consumers (Gao et al., 2017). Thus, the aim is not only to create value for the focal organization, but also to consider the needs of all 
stakeholders. Accordingly, innovativeness has been identified has a crucial capability needed to manage supply chains in social contexts compared to traditional SCM (Klassen \& Vereecke, 2012; Pagell \& Schevchenko, 2014; Longoni \& Cagliano, 2016). In our continuum, Coupled SISCM is a more innovative approach than Decoupled or Combinatory approaches. In Coupled SISCM, stakeholders typically associated to one core logic (i.e., social-welfare) are called to integrate elements from the other logic to effectively deliver a social mission. This requires innovative supply chain structures, roles and relationship management in the social enterprise's supply chain. Future research should investigate innovative SISCM strategies that social enterprises put in place to manage their supply chain and evaluate their effectiveness in enacting multiple logics, preventing mission drift, and improving their efficiency while maintaining their social commitment.

\section{Stakeholder identification and engagement}

Traditionally, organizations characterized by a commercial logic identify stakeholders accordingly to a firm's profit orientation as suggested by stakeholder theory (Freeman, 1984). In such a context, stakeholders have been classified as primary and secondary stakeholders (Clarkson, 1995). Primary stakeholders include those stakeholders continuously part of the value creation in the focal organization's supply network such as traditional suppliers and customers, a rather homogenous set of stakeholders characterized by profit orientation with clear roles in the focal organization's supply chain. If any primary stakeholder group, such as customers or suppliers, becomes dissatisfied the focal firm will be seriously damaged or unable to continue as a going concern. Secondary stakeholders are a more heterogeneous set of stakeholders including NGOs and mass media that are able to mobilize public opinion in favor of, or in opposition to, an organization. Traditionally, they have been considered as influencers, but they are not engaged in transactions with the corporation nor are they essential for its survival.

Conversely, focal organizations in SISCM identify stakeholders based on the combination of the social-welfare and commercial logics leading to different types of primary and secondary stakeholders. More specifically, in SISCM, primary stakeholders are characterized by greater heterogeneity than in traditional SCM. These actors include profit-oriented organizations such as good and service suppliers, private or corporate donors, as well as socially-oriented organizations such as other social entities and NGOs who are committed to the social mission of the focal 
organizations. All of these stakeholders take an active part in the supply chain, as volunteers, influencers or formal collaborators.

Each stakeholder is providing a different type of resource to the focal organization that is needed for its daily operations and can cover supply chain roles such as customers, supplier, intermediaries, distributors (Sodhi, 2015). In this context, those stakeholders normally considered secondary in traditional SCM and a source of pressure, could be identified as core actors in the focal organization's supply chain and are proactively engaged. This shift might require future research on how these stakeholders behave and take part in SISCM. Future research might deal with this research direction in descriptive and in normative ways.

Descriptive research opportunities: Identifying stakeholders' roles in SISCM. In traditional SCM, the roles of primary stakeholders such as suppliers and customers in value creation are clearly defined. They are economic actors participating in the physical and informational flows enabling the focal organization to produce and deliver its goods or services and taking a stake in the value created though economic transactions. In this context, the identification of stakeholders and their roles in the supply chain does not need specific analysis. But in SISCM, a focal organization has to identify who its primary stakeholders are in terms of profits vs non-profit, public vs private, and corporate vs citizens, which logic characterizes them and what their role is in the supply chain. It could be that in the supply chain of a social enterprise, NGOs might act as suppliers of information about people in need. This type of supplier will adopt a social-welfare logic in the way it acts and interacts with the social enterprise as opposed to a traditional supplier with a commercial logic. In some cases, NGOs act as intermediaries in the focal firm's supply chain with people in need. We expect NGOs to be a different kind of intermediary than traditional traders, as they prioritize a social-welfare logic and possess a different set of skills and capabilities. Also, in some cases, suppliers, distributors or customers might be people in need which might introduce sources of risk and uncertainty and thus require specific engagement mechanisms such as non-contractual arrangements and noncoercive power mechanisms. Therefore, focal organizations in SISCM need to understand who their stakeholders are, what their institutional logic(s) is, what role they play in their supply chain and how to engage them in achieving the focal organization's goals. 
Normative research opportunities: Balancing stakeholders' characteristics. The inclusion of stakeholders that are not profit-oriented might lead to suboptimal financial performance because of different priorities and working mechanisms. However, these actors are core to providing legitimation, social skills, and resources fundamental to the functioning of the focal organization's supply chain. Thus, focal organizations should be able to identify their stakeholders according to both social-welfare and commercial logics and balance them in order to achieve both social effectiveness and economic viability. Sodhi (2015) proposes the stakeholder resource based view (SRBV) as a framework to inform the decision-making of managers of a company towards maximizing their utility and also those of the company's stakeholders. Designing and managing supply chain partners with complementary capabilities has a positive impact on sustainability and value creation. Here, each stakeholder (or stakeholder group), with its individual view of the operations, has specific resources and capabilities. Therefore, the focal organization should be able to identify the resources needed according to both commercial and social-welfare logics and engage with a set of the stakeholders able to provide them.

\section{Relationship management}

Several disciplines have investigated inter-organizational relationships and their performance implications (Autry \& Golicic, 2010). In traditional SCM literature, according to the commercial logic, these studies have focused on buyer-supplier vertical relationships (Terpend et al., 2008) and several classifications have been provided (e.g., Ahmed et al., 2017; Tangpong et al., 2015; Terpend et al., 2012). Among them, Tangpong et al. (2015) proposed a classification based on two main aspects: relationalism, the degree to which buyer and supplier firms promote behaviours that maintain or improve their relationship, and power dependence such as buyer/supplier dependence.

We expect that in SISCM, focal organizations will establish relationships not only with traditional profit-oriented organizations as in traditional SCM, but with all stakeholders identified above. This will result in inter-organizational relationships with a distinctive character relative to traditional SCM relationships. We expect the peculiarities of such stakeholders to impact the balance as well as the content of relationalism and power dependence approaches. In contexts characterized by social-welfare logic stakeholders, relationships will have the goal of 
reciprocal exchange and will not only concern information, products, labor force, and/or financial means, but also more intangible elements such as compassion, education, and care (Tate \& Bals, 2016). This leads to a new research direction on how stakeholder relationships are managed in a context characterized by greater institutional complexity particularly combining social-welfare and commercial logics. This research topic can also be investigated in a descriptive and normative way.

\section{Descriptive research opportunities: Describing relationalism and power in SISCM. In} terms of relationalism, the combination of social-welfare logic with the commercial logic might require additional altruistic rather than purely economic motives to define stakeholder relationship management (Tate \& Bals, 2016). This can happen when the social enterprise is dealing with people in need, other social entities, or NGOs and it interacts with them in an altruistic fashion. On the other side, profit-oriented stakeholders, providing financial resources to the social enterprise, might act in an altruistic fashion toward the social enterprise if moved by shared goals or because of a desire to be associated with the social mission. This might require a new definition and typology of relationalism.

Additionally, power-dependence might be defined in a different way than in traditional SCM. In a commercial logic, the more powerful actor would likely exert control over the less powerful, possibly acting in its own interest. When an organization depends upon another for resources or performance and few alternative sources exist, we are likely to witness a powerdominated relationship. A classic example is when a buyer has power as a result of a high share of supplier revenues with that buyer and the availability of alternative suppliers or - vice versa a powerful supplier as a result of high asset specificity and a limited supplier pool. Instead of being based on a commercial logic, in SISCM, power might be defined according to a socialwelfare logic or a blend of the two logics. Based on a commercial logic, the social enterprise might be power dependent to market-entities because of funding and other resources needs. However, in a social-welfare logic, these organizations might have a different type of power in the relationship with market-entities, such as legitimacy-based and referent-based power which are proposed to be at the basis of social power (French \& Raven, 1959). Legitimacy-based forms of social power stem from internalized values by the stakeholders who recognize the social enterprise to have legitimate authority to influence them in a specific social context; referent- 
based forms of social power stem from the willingness of the stakeholders to be associated to the social organization and recognize its influence.

Normative research opportunities: Investing in trust-based relationships to contribute to network stability, social effectiveness and financial viability. Shared experiences and information exchanges are vitally important for the focal organization's management of many different types of stakeholder relationships to identify key collaborators in the supply chain whose interests align with the social enterprise's mission, such as public, private, hybrids, community, and third party financiers (Kolk and Lenfant, 2015). As the nature of these relationships moves toward extreme aspects of relationalism, such as altruism and legitimacyand referent-based power, institutional complexity might increase the role of trust in SISCM relative to traditional SCM. Trust refers to the confidence in another's goodwill and conformance to expectations (Ring \& Van de Ven, 1994). Even though there is evidence that trust can have a positive effect on supply chain relationships, power dynamics have traditionally dominated relationships in traditional SCM.

Power and trust exist as different means through which a firm seeks to promote desired behaviours in a partner. They are complementary and opposing components of social behaviour through which firms can adjust social relations to achieve a desired outcome (Ireland \& Webb, 2007). Usually one can substitute for another when one fails to achieve desired results. We propose that in an institutionally complex environment resulting from the combination of socialwelfare and commercial logics, trust-based relationship might be more effective than traditional power-based relationships. However, previous studies show that increasing amounts of informal trust-based relationships can magnify the chances of opportunistic behaviours (Ireland \& Webb, 2007). Another risk of an excess of trust is the over-embeddedness stemming from the emotional attachment and efficiency of high-trust relationships rather than looking for alternative partners that might increase its effectiveness. In SISCM, the focal organization might stick to stagnating relationships, eventually compromising the social mission achievement. These risks can be hedged through specific control mechanisms that prevent opportunistic behaviours and reward innovation. In this sense, power can become complementary to rather than conflicting with a trust-based relationship. Thus, future research might investigate all these different relational 
nuances in SISCM and the most effective way toward social mission achievement and financial viability.

\section{CONCLUSION}

Previous SCM research has mainly focused on ways to achieve economic goals when dealing with sustainability issues leading to "less harm" solutions. Research about NGOs or humanitarian logistics has focused on the study of supply chains that address temporary and local social needs. In this study, we highlight a gap in theorizing and investigate focal organizations who provide a social good with the intention of being financially viable in the long term. Thus, we propose a definition of SISCM and describe different approaches taken by focal organizations combining commercial and social-welfare logics.

Our contributions are twofold. First, we introduce the concept of social impact supply chain management. SISCM appears fundamentally distinct from traditional SCM in terms of supply chain strategy, stakeholder identification and engagement, and relationship management due to the combination of commercial and social-welfare logics in SCM decisions by the focal organization, a social enterprise. Second, we apply the lens of institutional logics and institutional complexity to highlight the hybrid and innovative nature of SISCM. This is another contribution to the literature and promises to serve as a useful theoretical framework to interpret how organizations manage their supply chains in presence of multiple conflicting logics, which is the typical situation when the mission is to create social good rather than just reduce harm.

Three different SISCM approaches of focal organizations characterized by different combinations of social-welfare and commercial logics have been provided. While these are not inclusive of all possible approaches, they are a starting point for future research to compare the various approaches. We can envisage that SISCM approaches may also influence traditional SCM strategies and practices. For example, several for-profit companies are showing signs of going beyond Decoupled SISCM in their effort to improve the conditions of people in-need across their supply chain while simultaneously achieving economic goals. Illy, a global coffee roaster has worked for decades to improve the working and living conditions of farmers as a social goal per se but also as a way to ensure the quality and sustainability of green coffee (Longoni \& Luzzini, 2016), and similar initiatives have been launched by companies like Nestle 
or Starbucks (Alvarez, Pilbeam, \& Wilding, 2010). Another popular example is the e-Choupal initiative of ITC Ltd. to improve the working and economic conditions of Indian farmers (Chen, George, \& Zuo-Jun, 2013) and thus improve the efficiency and effectiveness of its agriculture and aquaculture supply chain. These examples are different variations of Decoupled SISCM and Combinatory SISCM approaches. Future research might investigate the transition process of organizations from one SISCM approach to the other, possibly highlighting some intermediate stages in the continuum.

We hope that our study might pave the way to more research about how focal organizations characterized by the combination of commercial and social-welfare logics can manage their supply chain (i.e., SISCM). We define social enterprises in a broad sense to include all organizations which have a social mission to different extents. The focal organization could potentially be any type of organization ranging from for-profit, benefit or B corporations to social entities. What will distinguish their approaches will be whether the social-welfare logic is peripheral or core as well as the level of centrality.

We propose three main areas for future research directions for SISCM. First, future research might investigate the effectiveness of different innovative strategies adopted by focal organizations to manage the internal and external institutional complexity deriving from the combination of commercial and social-welfare logics in the supply chain (Greenwood et al. 2011; Kraatz \& Block, 2008) as well related risks (Sodhi, 2015). Second, because the boundaries between the social-welfare and commercial logics in SISCM are often blurred, this makes the identification of stakeholders taking part in supply chain activities more challenging. Future research might investigate the roles of non-traditional stakeholders in SISCM such as NGOs, governments, and people-in need who can act as suppliers, distributors, intermediaries or customers. Third, regarding relationship management, future research might investigate the stakeholder-social enterprise relationship typologies and their effectiveness in addressing the institutional complexity emerging from the social-welfare and commercial logics.

We focused on three main areas where we felt SISCM might be different from traditional SCM. There are other areas where the SISCM might differ. In particular, performance measurement and management will be quite different. In SISCM, both financial outcomes and social impact measures will have importance for the focal organizations which has managerial implications for interacting with supply chain members and ongoing viability. For example, in 
Decoupled SISCM, the focal organizations often use strict time lines to track proof of concept and a payback schedule as well as specific measures of social impact such as the count of specific illnesses correlated with sales regions. Companies like SC Johnson terminate initiatives

if pre-defined financial criteria are not met (Simanis \& Duke, 2014). On the other hand, in Combinatory and Coupled SISCM, the targeted social group has an active role in the supply chain and a key performance metric is the number of people employed as well as measures of their well-being such as health, education, and literacy. While financial viability is important, specific "cut-off" metrics would not be the norm. Future research might consider comparing social impact performance management approaches as well as metrics such as duration of impact, scope and depth, scalability of approach, as well as indicators of mission drift and flexibility around initiative termination.

Our fundamental argument is that hybrid innovative SISCM approaches emerging from the combination of social-welfare and commercial logics can foster social impact effectiveness in economically viable organizations. However, we do not deny the drawbacks and tensions arising from SISCM related to sub-optimal economic outcomes compared to traditional SCM or exposure to social mission drift. Thus, we encourage future researchers to explore this rich and complex area to understand how we can create more socially effective organizations and supply chains.

\section{REFERENCES}

Ahmed, M. U., Kristal, M. M., Pagell, M., \& Gattiker, T. F. (2017). Towards a classification of supply chain relationships: a routine based perspective. Supply Chain Management: An International Journal, 22(4), 341-374.

Akhtar P., Marr, N.E., \& Garnevska, E.V. (2012). Coordination in humanitarian relief chains: chain coordinators. Journal of Humanitarian Logistics and Supply Chain Management, 2(1), 85-103.

Alvarez, G., Pilbeam, C., \& Wilding, R. (2010). Nestlé Nespresso AAA sustainable quality program: an investigation into the governance dynamics in a multi-stakeholder supply chain network. Supply Chain Management: An International Journal, 15(2), 165-182.

Autry, C. W., \& Golicic, S. L. (2010). Evaluating buyer-supplier relationship-performance spirals: A longitudinal study. Journal of Operations Management, 28(2), 87-100.

B Lab (2018). What are B Corps? https://www.bcorporation.net/what-are-b-corps Accessed on January 11, 2018.

Bals, L. \& Tate, W. (2017): What Hybrid Business Models can Teach Sustainable Supply Chain Management: The Role of Entrepreneurs' Social Identity and Social Capabilities. In: 
Brandenburg, M., Hahn, G. \& Rebs, T. (Eds.), Social and Environmental Dimensions of Organizations and Supply Chains - Tradeoffs and Synergies, Greening of Industry Networks Studies, Springer.

Bartlett, C. (2017) Unilever's Lifebuoy in India: Implementing the Sustainability Plan. Harvard Business School Case \#9-914-417, March 8.

Battilana, J., \& Lee, M. (2014). Advancing research on hybrid organizing-Insights from the study of social enterprises. Academy of Management Annals, 8(1), 397-441.

Ben \& Jerry’s (2018). Ben \& Jerry’s Partnershops ${ }^{\circledR}$ Program.

https://www.benjerry.com/values/how-we-do-business/partnershops, Accessed January 24, 2018.

Besharov, Marya L., and Wendy K. Smith. "Multiple institutional logics in organizations: Explaining their varied nature and implications." Academy of Management Review 39, no. 3 (2014): 364-381.

Bhattacharyya, O., Khor, S., McGahan, A., Dunne, D., Daar, A. S., \& Singer, P. A. (2010). Innovative health service delivery models in low and middle income countries-what can we learn from the private sector? Health Research Policy and Systems, 8(1), 24.

Brugmann, J., \& Prahalad, C. K. (2007). Cocreating business's new social compact. Harvard business review, 85(2), 80.

Chen, Y. J., J George, S., \& Zuo-Jun M ax, S. (2013). Training, Production, and Channel Separation in ITC's E-Choupal Network. Production and Operations Management, 22(2), 348-364.

Christopher, M., \& Towill, D. R. (2000). Supply chain migration from lean and functional to agile and customised. Supply Chain Management: An International Journal, 5(4), 206-213.

Clarkson, M. E. (1995). A stakeholder framework for analyzing and evaluating corporate social performance. Academy of management review, 20(1), 92-117.

Dacin, M.T., Dacin, P.A., \& Tracey, P. (2011). Social entrepreneurship: a critique and future directions. Organization Science, 22(5), 1203-1213.

Dacin, P.A., Dacin, M.T., \& Matear, M. (2010). Social entrepreneurship: why we don't need a new theory and how we move forward from here. Academy of Management Perspectives, 24, 37-57.

Dees, G. \& Elias, J. (1998). The challenges of combining social and commercial enterprise. Business Ethics Quarterly, 8 (1), 165-78.

The Economist (2017). Charities are becoming more professional. The Economist, September $30^{\text {th }}$ - October $6^{\text {th }}$.

The Economist (2017). America Inc gets woke. The Economist, December $2^{\text {nd }}-8^{\text {th }}$.

Fisher, M., Hammond, J., Obermeyer, W., \& Raman, A. (1997). Configuring a supply chain to reduce the cost of demand uncertainty. Production and Operations Management, 6(3), 211225.

Freeman, R. E. (1984). Strategic planning: A stakeholder approach. Pitman, Boston. 
French, R.P. \& Raven, B.H. (1959). The bases of social power. In: Cartwright, D. (Ed.), Studies in Social Power. University of Michigan Press, Ann Arbor, MI, pp. 155-164.

Friedland, R., \& Alford, R.R. (1991). Bringing society back in: Symbols, practices, and institutional contradictions. In W.W. Powell \& P.J. DiMaggio (Eds.), The new institutionalism in organizational analysis (pp. 232-266). Chicago: University of Chicago Press.

Gao, D., Xu, Z., Ruan, Y. and Haiyan, L. (2017). From a systematic literature review to integrated definition for sustainable supply chain innovation (SSCI). Journal of Cleaner Production, 142,1518-1538.

Greenwood, R., Raynard, M., Kodeih, F., Micelotta, E. R., \& Lounsbury, M. (2011). Institutional complexity and organizational responses. The Academy of Management Annals, 5(1), 317371.

Gulati, R., \& Puranam, P. (2009). Renewal through reorganization: The value of inconsistencies between formal and informal organization. Organization Science, 20(2), 422-440.

Ireland, R. D., \& Webb, J. W. (2007). A multi-theoretic perspective on trust and power in strategic supply chains. Journal of Operations Management, 25(2), 482-497.

Kantarjian, H. (2015). High cost of cancer drugs goes beyond price, http://www.modernhealthcare.com/article/20150404/MAGAZINE/304049978 , Accessed July 19, 2017.

Karnani, A. (2007). The mirage of marketing to the bottom of the pyramid: How the private sector can help alleviate poverty. California Management Review, 49(4), 90-111.

Klassen, R. D., \& Vereecke, A. (2012). Social issues in supply chains: Capabilities link responsibility, risk (opportunity), and performance. International Journal of Production Economics, 140(1), 103-115.

Knuckles (2016). The role of hybrid stakeholders in the supply chain for d.light solar lanterns and solar home systems sold in Haiti. Presented at EUROMA Sustainability Forum, Milan, Italy.

Kraatz, M. S., Block, E. S. (2008). Organizational implications of institutional pluralism. The Sage Handbook of Organizational Institutionalism, 840, 243-275.

Kolk, A., \& Lenfant, F. (2015). Cross-sector collaboration, institutional gaps, and fragility: the role of social innovation partnerships in a conflict-affected region. Journal of Public Policy \& Marketing, 34(2), 287-303.

Lander, N. (2017). Coffee Break. Financial Times Weekend, December 30 \& 31, 8.

Lee, H. L. (2002). Aligning supply chain strategies with product uncertainties. California Management Review, 44(3), 105-119.

Lee, H.L., \& Tang, C.S. (2017). Socially and environmentally responsible value chain innovations: new operations management research opportunities. Management Science, forthcoming. 
Lewis, D. (2015). Why a single vial of antivenom can cost \$14,000: it's not because all antivenom is expensive to make, http://www.smithsonianmag.com/smart-news/why-singlevial-antivenom-can-cost-14000-180956564/ Access July 19, 2017.

Liao, C. N., \& Chen, Y. J. (2017). Farmers' Information Management in Developing CountriesA Highly Asymmetric Information Structure. Production and Operations Management, forthcoming.

Longoni, A., \& Cagliano, R. (2016). Sustainable innovativeness and the triple bottom line: The role of organizational time perspective. Journal of Business Ethics, 1-24.

Longoni, A., \& Luzzini, D. (2016). Building Social Capital into the Disrupted Green Coffee Supply Chain: Illy’s Journey to Quality and Sustainability. In Organizing Supply Chain Processes for Sustainable Innovation in the Agri-Food Industry (pp. 83-108). Emerald Group Publishing Limited.

Longoni, A., Luzzini, D. \& Pullman, M. (2017). Mescaldis: Social entrepreneurship in supply chain management. Proceedings from EUROMA Sustainability Forum, Milan.

Mair, J., Battilana, J., \& Cardenas, J. (2012). Organizing for society: A typology of social entrepreneuring models. Journal of Business Ethics, 111(3), 353-373.

Mapelli, F., Arena, M., \& Strano, P. (2016). Inclusive innovation and the role of partnerships: The case of Semi Di Libertà. In Organizing Supply Chain Processes for Sustainable Innovation in the Agri-Food Industry, Organizing for Sustainable Effectiveness, 5, 261-286.

Meyer, J. W., \& Rowan, B. (1977). Institutionalized organizations: Formal structure as myth and ceremony. American journal of sociology, 83(2), 340-363.

McKibben, B. (2017). Power brokers: Africa’s solar boom is changing life beyond the grid. The New Yorker, June 26, 46-55.

Moon, J. \& Sochacki, R. (1996). The social responsibility of business in job and enterprise creation: Motives, means and implications. The Australian Quarterly, 68(1), 11-30.

Pache, A. C., \& Santos, F. (2010). When worlds collide: The internal dynamics of organizational responses to conflicting institutional demands. Academy of Management Review, 35(3), 455476.

Pache, A. C., \& Santos, F. (2013). Inside the hybrid organization: Selective coupling as a response to competing institutional logics. Academy of Management Journal, 56(4), 9721001.

Pagell, M., \& Shevchenko, A. (2014). Why research in sustainable supply chain management should have no future. Journal of Supply Chain Management, 50(1), 44-55.

Pagell, M., \& Wu, Z. (2009). Building a more complete theory of sustainable supply chain management using case studies of 10 exemplars. Journal of Supply Chain Management, 45(2), 37-56.

Prahalad, C. K., \& Hart, S. L. (2002), —The Fortune at the Bottom of the Pyramid, Strategy + Business, 26, 2-14. 
Ramus, T., Vaccaro, A., \& Brusoni, S. (2017). Institutional complexity in turbulent times: formalization, collaboration, and the emergence of blended logics. Academy of Management Journal, 60(4), 1253-1284.

Ring, P. S., \& Van de Ven, A. H. (1994). Developmental processes of cooperative interorganizational relationships. Academy of Management Review, 19(1), 90-118.

Rodríguez, J. A., Giménez Thomsen, C., Arenas, D., \& Pagell, M. (2016). NGOs’ initiatives to enhance social sustainability in the supply chain: poverty alleviation through supplier development programs. Journal of Supply Chain Management, 52(3), 83-108.

Sawal, N., Venkateswaran, J., Solanki, C.S., \& Narayanan, N.C. (2015). Million Solar Urja Lamp Programme: A Supply Chain Experience. Proceedings of the 2015 IEEE International Conference on Industrial Engineering and Engineering Management, Singapore, 342-346.

Simanis, E., \& Duke, D. (2014). Profits at the bottom of the pyramid. Harvard Business Review, 92(10), 86-93.

Sodhi, M. S. (2015). Conceptualizing Social Responsibility in Operations Via Stakeholder Resource-Based View. Production and Operations Management, 24(9), 1375-1389.

Sodhi, M. S., \& Tang, C. S. (2011). Social enterprises as supply-chain enablers for the poor. Socio-Economic Planning Sciences, 45(4), 146-153.

Sodhi, M. S., \& Tang, C. S. (2016). Supply chain opportunities at the bottom of the pyramid. Decision, 43(2), 125-134.

Stock, J. R., \& Boyer, S. L. (2009). Developing a consensus definition of supply chain management: a qualitative study. International Journal of Physical Distribution \& Logistics Management, 39(8), 690-711.

Tangpong, C., Michalisin, M. D., \& Melcher, A. J. (2008). Toward a Typology of BuyerSupplier Relationships: A Study of the Computer Industry*. Decision Sciences, 39(3), 571593.

Tangpong, C., Michalisin, M. D., Traub, R. D., \& Melcher, A. J. (2015). A review of buyersupplier relationship typologies: progress, problems, and future directions. Journal of Business \& Industrial Marketing, 30(2), 153-170.

Tate, W. L., \& Bals, L. (2016). Achieving Shared Triple Bottom Line (TBL) Value Creation: Toward a Social Resource-Based View (SRBV) of the Firm. Journal of Business Ethics, 124.

Terpend, R., Tyler, B. B., Krause, D. R., \& Handfield, R. B. (2008). Buyer-Supplier Relationships: Derived Value Over Two Decades. Journal of Supply Chain Management, 44(2), 28-55.

Terpend, R., \& Ashenbaum, B. (2012). The intersection of power, trust and supplier network size: Implications for supplier performance. Journal of Supply Chain Management, 48(3), 52-77.)

Thornton, P. H. (2004). Markets from culture: Institutional logics and organizational decisions in higher education publishing. Stanford University Press. 
Vellema, S., \& van Wijk, J. (2015). Partnerships intervening in global food chains: the emergence of co-creation in standard-setting and certification. Journal of Cleaner Production, 107, 105-113.

Womack, J. P., \& Jones, D. T. (2010). Lean thinking: banish waste and create wealth in your corporation. Simon and Schuster.

Woodyard, C., \& Layton, M.J. (2016). Massive price increases on EpiPens raise alarm. https://www.usatoday.com/story/money/business/2016/08/22/two-senators-urge-scrutinyepipen-price-boost/89129620/ Accessed on July 19, 2017.

Yunus (2018). CIFEA: Supply chain development for honey farmers in Tunisia. http://www.yunussb.com/portfolio/cifea/ from Yunus Social Business. Accessed on January 8, 2018. 
Figure 1

\section{Continuum of SISCM approaches}

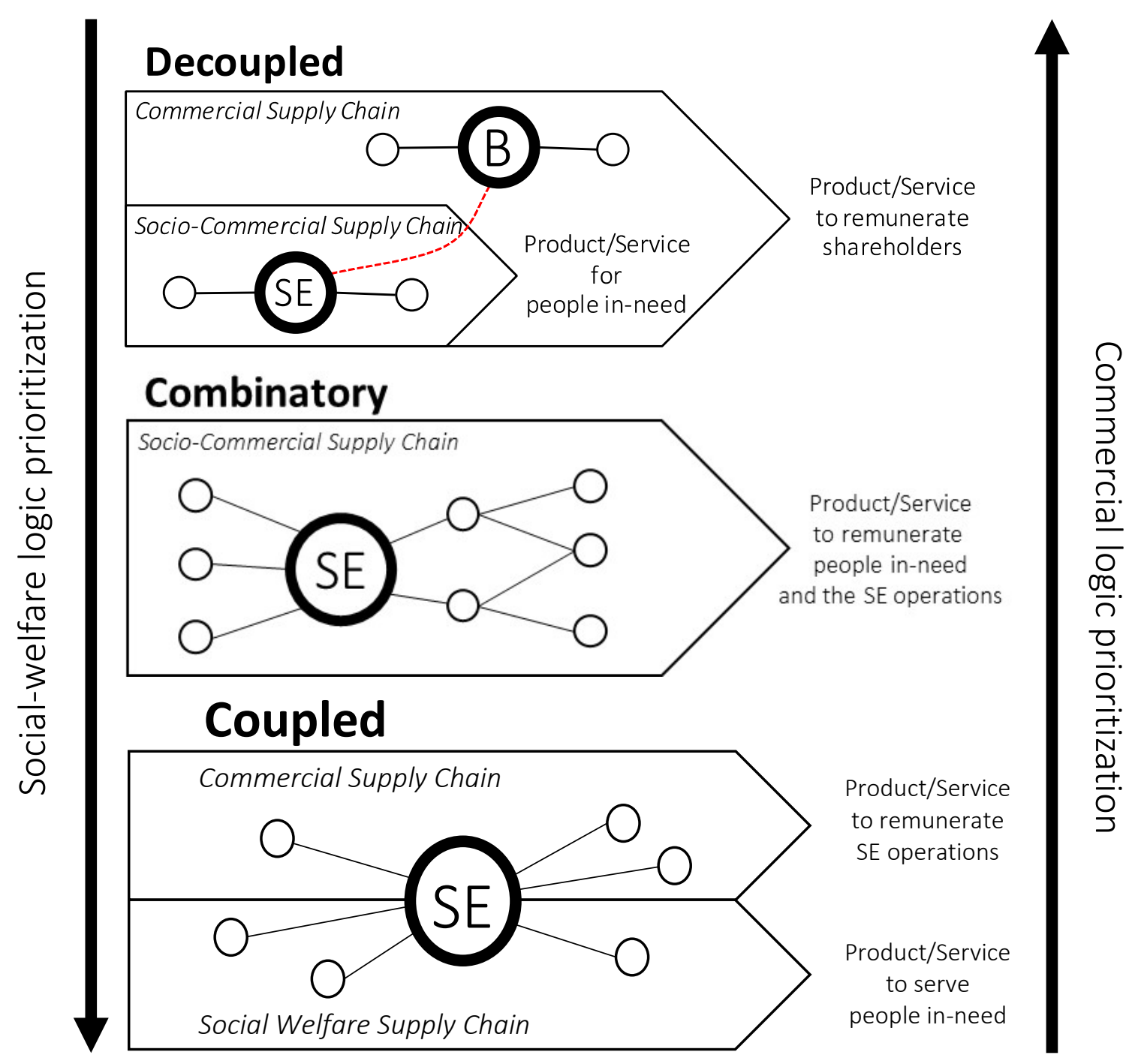




\section{Table 1}

\section{SISCM approaches summary}

\begin{tabular}{|c|c|c|c|c|}
\hline & & Decoupled (Commercial) & Combinatory & Coupled (Social) \\
\hline \multirow[t]{2}{*}{ Context } & Focal organization & $\begin{array}{l}\text { Multinational company/corporation } \\
\text { or subsidiary }\end{array}$ & Social enterprise & Social enterprise \\
\hline & Institutional complexity & $\begin{array}{l}\text { Commercial logic core, social- } \\
\text { welfare logic peripheral }\end{array}$ & $\begin{array}{l}\text { Commercial and social-welfare } \\
\text { logic centrality }\end{array}$ & Social-welfare logic core, commercial logic peripheral \\
\hline \multirow[t]{5}{*}{ SISCM strategy } & SISCM definition & $\begin{array}{l}\text { The for-profit focal organization } \\
\text { develops and manages a SC to } \\
\text { address business opportunities in } \\
\text { emerging markets. }\end{array}$ & $\begin{array}{l}\text { The social enterprise focal } \\
\text { organization develops and } \\
\text { manages a SC combining social } \\
\text { and market logics }\end{array}$ & $\begin{array}{l}\text { The social enterprise focal organization develops and manages } \\
\text { two supply chains, a "pure" social supply chain to deliver a } \\
\text { social service and a commercial supply chain to sell a } \\
\text { product/service }\end{array}$ \\
\hline & Primary SISCM purpose & Profit & Social and profit & $\begin{array}{l}\text { Social and economic independence to serve the ultimate social } \\
\text { goal }\end{array}$ \\
\hline & $\begin{array}{l}\text { Social provisional category } \\
\text { design }\end{array}$ & $\begin{array}{l}\text { Design product/service for people } \\
\text { in need }\end{array}$ & $\begin{array}{l}\text { Design a SC to include people } \\
\text { in need in economic activities }\end{array}$ & $\begin{array}{l}\text { Design a SC to provide skills and opportunities for people in } \\
\text { need }\end{array}$ \\
\hline & $\begin{array}{l}\text { Focal organization } \\
\text { operations management }\end{array}$ & $\begin{array}{l}\text { Sell and distribute the product in } \\
\text { emerging/bottom of the pyramid } \\
\text { markets }\end{array}$ & $\begin{array}{l}\text { Share information, provide } \\
\text { resources and train people in- } \\
\text { need }\end{array}$ & $\begin{array}{l}\text { Manage flexible operations combining the social and commercial } \\
\text { supply chains }\end{array}$ \\
\hline & $\begin{array}{l}\text { Focal organization supplier } \\
\text { management }\end{array}$ & $\begin{array}{l}\text { Build and coordinate a local } \\
\text { "commercial" SC (e.g., connect } \\
\text { with local partners and NGOS) to } \\
\text { deliver a product/service to local } \\
\text { people }\end{array}$ & $\begin{array}{l}\text { Connect people in need with } \\
\text { local and international } \\
\text { commercial organizations (e.g., } \\
\text { reduce tiers for better selling } \\
\text { prices, provide contacts with } \\
\text { customers, use them for last } \\
\text { mile distribution) }\end{array}$ & $\begin{array}{l}\text { Build a social SC to bring social issues from social entities to } \\
\text { economic entities filling institutional voids; and an economic SC } \\
\text { acting as a supplier/buyer in the market. }\end{array}$ \\
\hline \multirow{4}{*}{$\begin{array}{l}\text { Stakeholder } \\
\text { identification and } \\
\text { engagement }\end{array}$} & Customers & People in need & Consumer/Clients & $\begin{array}{l}\text { Social SC: People in need } \\
\text { Commercial SC: Consumer/Clients }\end{array}$ \\
\hline & Suppliers/Distributors & For-profit organizations & People in need & $\begin{array}{l}\text { Social SC: Social entities } \\
\text { Commercial SC: For-profit and/or not for-profit organizations }\end{array}$ \\
\hline & Intermediaries & NGOs, social entities, governments & $\begin{array}{l}\text { NGOs, social entities, } \\
\text { governments }\end{array}$ & $\begin{array}{l}\text { Social SC: Social-oriented organizations } \\
\text { Commercial SC: For-profit and/or for-profit organizations }\end{array}$ \\
\hline & Financing entities & Banks, shareholders & $\begin{array}{l}\text { Local entrepreneur networks, } \\
\text { donors, governments }\end{array}$ & $\begin{array}{l}\text { Social SC: Local entrepreneur networks, donors, governments } \\
\text { Commercial SC: Banks, shareholders }\end{array}$ \\
\hline \multirow[t]{2}{*}{$\begin{array}{l}\text { Relationship } \\
\text { management }\end{array}$} & Relationalism approach & Transactional & Altruistic & $\begin{array}{l}\text { Social SC:, Altruistic } \\
\text { Commercial SC: Transactional }\end{array}$ \\
\hline & Power dominance & $\begin{array}{l}\text { Power-based } \\
\text { Legitimacy-based with } \\
\text { Suppliers/Distributors }\end{array}$ & $\begin{array}{l}\text { Trust-based } \\
\text { Power-based with Customers }\end{array}$ & $\begin{array}{l}\text { Social SC: } \\
\text { Referent-based with Clients and Suppliers/Distributors } \\
\text { Trust-based with Intermediaries and Financing entities } \\
\text { Commercial SC: } \\
\text { Referent-based with Customers } \\
\text { Trust-based with Suppliers/Distributors } \\
\end{array}$ \\
\hline
\end{tabular}

